\title{
Mandatory AIDS tests on basis 'of slight suspicion' in Bavaria
}

\section{Munich}

DEEPLY disturbed by the civil rights implications of a Bavarian court decision announced on 31 May, three West German AIDS foundations are considering an appeal to the nation's highest court.

The Bavarian court, the Bayerischer Verwaltungsgericht, declared in an oral statement that a person can be forced by local health officials to be tested for antibodies to the human immunodeficiency virus (HIV) on the basis of even a "slight suspicion" of being infected. HIV is the virus that causes AIDS. Previously, a test could be required only if police proved to health officials that the person had been a member of a risk group such as intravenous drug users.

The case involves a man from the Rosenheim area who was an intravenous drug user until 1983. He had been tested for HIV with negative results in February 1985 after undergoing therapy. Another test was called for by police in June 1987, after the man had been found in possession of illegal but non-intravenous drugs such as hashish. The man then sought protection from the courts. A lower court upheld his refusal, but this ruling was overturned by the 31 May decision.

The foundations - the Deutsche AIDS-Stiftung (DAS), the Bayerische AIDS-Stiftung and the Nationale AIDSStiftung - view the higher court's ruling with mixed feelings. The court did not base its decision on the controversial "AIDS catalogue" of the Bavarian government, but rather solely on the federal epidemic law (Bundesseuchengesetz). This undermines the validity of the Bavarian measures, which have until now been condemned by the West German government and the other 10 Länder (states) (see Nature 327, 264; 1987). But the court's interpretation of the federal epidemic law might cause the other Länder to re-evaluate their policies and allow mandatory tests. Further clarification is expected when the court releases a written brief on the case.

The court justified its decision orally based on its judgement that the public's right to protection from AIDS outweighs the infected person's right not to know about his infection. The statement did not touch on the civil rights issues involved.

The ruling will not necessarily affect the way in which other cities in Bavaria interpret the law. In Munich, Senior City Administrator Hans-Peter Uhl stands by a "humane application" of the law which requires that the police give evidence of intravenous drug use or other risky behaviour before he will call for a test. Without such a humane approach, Uhl said, there is a risk of returning to the "dark Middle Ages" when diseased people were "driven beyond the city wall." Uhl said that prostitutes and foreigners in Munich have been very cooperative about being tested in the year since the law took effect. A legal challenge to the recent ruling may be difficult or even undesirable, said Ulrich Heide, managing director of the DAS in Cologne. The case cannot be brought to the highest German court, the Federal Constitutional Court (Bundesverfassungsgericht), by anyone but the original defendant or the Bundestag (federal parliament). But by the time the Rosenheim man can make a legal challenge, the test may already have been carried out. Heide said that the DAS would not push the man to make a challenge, though it would probably help pay the legal costs in such a case.

A challenge might be undesirable because of the perceived conservative bias of the Federal Constitutional Court. Even a discussion of the matter by the Bundestag might be harmful in Heide's opinion. The best outcome, he said, would be a return to the "status quo ante of broad political consensus for education and information". But this is unlikely to be the last case of its kind.

\section{Sober side up at giant AIDS meeting held in Stockholm \\ Stockholm}

Almost 100,000 cases of AIDS have now been reported to the World Health Organization (WHO) and probably an equal number are unreported, said Jonathan Mann, director of WHO's Global Programme on AIDS at the opening of the IV International Conference on AIDS in Stockholm last Sunday. He predicts that there will be at least a million new cases over the next five years.

Of these, some 300,000 are likely to be in the United States according to the latest predictions of the US Centers for Disease Control (CDC), although the confidence limits on these predictions are far from high. Even now, said CDC director James Curran, one new US case of AIDS is being reported every 14 minutes.

For Europe, Jean-Baptiste Brunet, of the Claude Bernard Hospital in Paris, predicted a cumulative total of 56,400 AIDS cases by the end of 1989 , with a large increase in the proportion of cases associated with intravenous drug use, particularly in southern Europe.

No predictions are possible for Africa for a variety of reasons, one of which is that the availability of adequate figures on the proportion of people already infected with the human immunodeficiency virus (HIV) is patchy. At least in Kinshasa, capital of Zaïre, it is certain that between about 3 and 7 per cent of blood donors, pregnant women and factory or bank workers are infected. The brighter side of these figures is that they have remained constant for up to four years, said Bosenge N'Galy from Zaïre's Department of Public Health.

As if the epidemiologist's figures were not sobering enough, Sweden's Prime Minister Ingvar Carlsson had opened the conference by warning the delegates of winning the battle against AIDS in the laboratory but losing it in the streets. And
Robert Gallo of the National Cancer Institute in Bethesda said that laboratory research was now in a period of steady incremental progress rather than the dramatic advances of the first few years.

Nevertheless, both Gallo and Luc Montagnier from the Pasteur Institute were able to provide delegates with a few new facts to whet their appetites. Montagnier referred to emerging evidence that rhesus macaque monkeys infected with HIV-2, the predominant HIV in West Africa, develop AIDS-like symptoms. If this is confirmed, AIDS research may at last have an animal model. He also predicted that serum antibodies to the product of the HIV nef gene (to use the new nomenclature - see Nature 333, 504; 1988) would become an earlier indication of HIV infection than other antibodies.

Gallo drew attention to accumulating evidence that human herpes virus 6 , recently discovered in his laboratory, is a cofactor in the progression from HIV infection to AIDS, and to laboratory data that suggest that Kaposi's sarcoma in AIDS patients is not the result of a second infectious agent. Instead it seems to be caused by a novel growth factor released by HIV-infected cells.

On the prospect of vaccines, Gallo was less bullish than in previous years, although still "confident that the problem will be solved". And Lars Olof Kallings, chairman of the conference, expressed disappointment that so few new compounds with activity against HIV were due to be reported.

The conference was attended by 7,000 plus delegates with 9 simultaneous sessions of workshops and round tables and over 3,000 posters. Delegate registration was greater than last year, with about 2,500 from North America and even more than that from Europe. Peter Newmark 